\title{
Consumer preference and the technological, cooking and nutritional quality of carioca beans
}

\section{Preferência do consumidor, qualidade tecnológica, culinária e nutricional de feijão carioca}

\author{
Nerinéia Dalfollo Ribeiro ${ }^{1 *}$; Cleiton Renato Casagrande ${ }^{2}$; Henrique Caletti \\ Mezzomo $^{3}$; Greice Rosana Kläsener ${ }^{2}$; Skarlet De Marco Steckling ${ }^{3}$
}

\begin{abstract}
Carioca beans will achieve better consumer acceptability if they exhibit high grain quality. The objectives of this work were to identify the visual quality traits that determine consumer choice of carioca beans; to evaluate whether the commercial brands of carioca beans present differences in their technological, cooking and nutritional quality traits; and to select the best commercial brand of carioca beans according to these traits using a selection index. For this purpose, six different commercial brands of carioca beans were evaluated with respect to consumer preference and their grain physicochemical traits. The visual quality traits, colour and grain size, defined the consumer choice of carioca beans. The commercial brands of carioca beans presented differences regarding their technological, cooking and nutritional quality traits. Brand 4 had lighter colour grains $\left(\mathrm{L}^{*}=53.33\right)$, a slightly red shade $\left(\mathrm{a}^{*}=6.20\right)$, medium-sized beans ( $27.52 \mathrm{~g}$ ), an elliptical shape, a semi-full flatness, and a fast cooking time (15 min and $25 \mathrm{~s}$ ). The brand 4 showed high concentrations of protein, potassium, phosphorus, calcium, zinc and copper, and this sample was the preference of $51.92 \%$ of the survey participants. The best commercial brand of carioca beans selected by the selection index was brand 4 for its technological, cooking and nutritional quality traits.
\end{abstract}

Key words: Phaseolus vulgaris L. Grains standard. Cooking time. Protein. Minerals.

\section{Resumo}

O feijão carioca terá maior aceitação pelos consumidores se apresentar alta qualidade de grãos. Os objetivos deste trabalho foram identificar caracteres da qualidade visual dos grãos que determinam a escolha do feijão carioca, avaliar se marcas comerciais de feijão carioca diferem para os caracteres da qualidade tecnológica, culinária e nutricional e selecionar marcas comerciais de feijão carioca superiores para esses caracteres, pelo uso de índice de seleção. Para tanto, seis diferentes marcas comerciais de feijão carioca foram avaliadas em relação a preferência dos consumidores e quanto às características físicas e químicas dos grãos. Os caracteres da qualidade visual - cor e tamanho dos grãos, definiram a escolha do consumidor de feijão carioca. As marcas comerciais de feijão carioca diferem para os caracteres da qualidade tecnológica, culinária e nutricional. A amostra da marca 4 possui grãos mais claros $\left(\mathrm{L}^{*}=53,33\right)$, levemente avermelhados $\left(\mathrm{a}^{*}=6,20\right)$, de tamanho médio $(27,52 \mathrm{~g})$, elípticos, de

${ }^{1}$ Prof $^{\mathrm{a}} \mathrm{Dr}^{\mathrm{a}}$, Departamento de Fitotecnia, Universidade Federal de Santa Maria, UFSM, Santa Maria, RS, Brasil. E-mail: nerineia@ hotmail.com

2 Discentes, Curso de Graduação em Agronomia, UFSM, Santa Maria, RS, Brasil. E-mail: cleiton_casagrande@hotmail.com; rosanaklasener@hotmail.com

3 Discentes, Curso de Mestrado do Programa de Pós-Graduação em Agronomia, UFSM, Santa Maria, RS, Brasil. E-mail: hc mezzomo@hotmail.com; kati_ste@hotmail.com

* Author for correspondence 
grau de achatamento semi-cheio e de cozimento rápido ( 15 min e $25 \mathrm{~s}$ ). Essa amostra mostrou altas concentrações de proteína, potássio, fósforo, cálcio, zinco e cobre e obteve a preferência de $51,92 \%$ dos avaliadores. A melhor marca comercial de feijão carioca selecionada pelo índice de seleção foi a marca 4 para os caracteres da qualidade tecnológica, culinária e nutricional.

Palavras-chave: Phaseolus vulgaris L. Padrão de grãos. Tempo de cozimento. Proteína. Minerais.

\section{Introduction}

Beans (Phaseolus vulgaris L.) can be found in a large variety of colours, sizes and shapes, and they serve diverse tastes. In Brazil, $79 \%$ of the most consumed common beans are the carioca type (beige seed coat with brown streaks) belonging to the Mesoamerican gene pool (CARNEIRO et al., 2012). For this reason, breeding programmes have prioritized the development of carioca bean cultivars, aiming to meet the demand of growers, traders and consumers.

If a carioca bean cultivar exhibits grain traits that satisfy consumer preference, consumption of beans of this type will increase, and more production will be demanded. Thus, it is important to evaluate which carioca bean traits define consumer choice. According to Gathu et al. (2012), African bean consumers consider two sensory quality traits of beans, the grain colour and size, which are visually evaluated. However, no previous studies were found in the literature determining which sensory quality traits of the grains best define consumer choice for a given commercial brand of carioca beans.

In carioca beans, the colour of the grains is associated with the cooking time. Carioca bean darkening showed a high correlation with cooking time $(r=0.6942)$ when the colour of the grains was visually evaluated 60 days after harvest (ARAÚJO et al., 2012). An increase in cooking time was significantly correlated with the colour parameters $\mathrm{L}^{*}, \mathrm{a}^{*}$ and $\mathrm{b}^{*}$ in carioca beans (SIQUEIRA et al., 2014). Thus, sensorial quality traits evaluated visually or by instruments are associated with cooking quality traits in carioca beans. However, no studies regarding the associating sensory quality traits of carioca beans with nutritional quality traits were found in the literature. When consumers choose a given commercial brand of carioca beans based on sensory quality traits, are they buying beans that are freshly harvested, have a fast cooking time and have high nutritional value?

Breeding programmes have emphasized the development of new carioca bean cultivars with high technological and cooking quality. The priority in selection has been of carioca bean lines that have lighter grains (ARNS et al., 2018; RIBEIRO et al., 2008), a mass of 100 grains between 25 and $30 \mathrm{~g}$, an elliptical shape, a semi-full degree of grain flatness (CARBONELL et al., 2010; SANTOS et al., 2016) and a cooking time less than $25 \mathrm{~min}$ (RIBEIRO et al., 2013a; SANTOS et al., 2016; STECKLING et al., 2017). Advances have also been made in nutritional quality breeding through the development of carioca bean lines with high concentrations of proteins (MINGOTTE et al., 2013; PEREIRA et al., 2017; SILVA et al., 2012) and minerals (JOST et al., 2013; MAZIERO et al., 2015; RIBEIRO et al., 2013a, b; SILVA et al., 2012; STECKLING et al., 2017) in the grains. However, no previous works were found in the literature assessing whether carioca beans available in the market exhibit high visual, technological, cooking and nutritional quality. This is important to evaluate whether the improvements to carioca bean cultivars are already available in the market and meet consumer preferences.

Thus, this work aimed (1) to identify which visual quality traits determine consumer choice for a given commercial brand of carioca beans; (2) to evaluate whether the commercial brands of carioca beans exhibit differences in their technological, cooking and nutritional grain quality traits; and (3) to select the best studied commercial brand of carioca beans according to these traits. 


\section{Material and Methods}

Six different Brazilian commercial brands of carioca beans were purchased from supermarkets in Santa Maria, Rio Grande do Sul, Brazil, in August 2017 (Figure 1). These samples represent the commercial brands of carioca beans most widely marketed in supermarkets in southern Brazil. All samples were found in the main supermarkets in Santa Maria in $1 \mathrm{~kg}$ packages and had a similar shelf life. The analysis was performed one week after the acquisition of the grains and was completed within 30 days. The grains were stored under refrigeration (temperature of $5{ }^{\circ} \mathrm{C}$ and air relative humidity of $75 \%$ ) during the assessment period.

Figure 1. Images of the commercial brands of carioca beans evaluated.

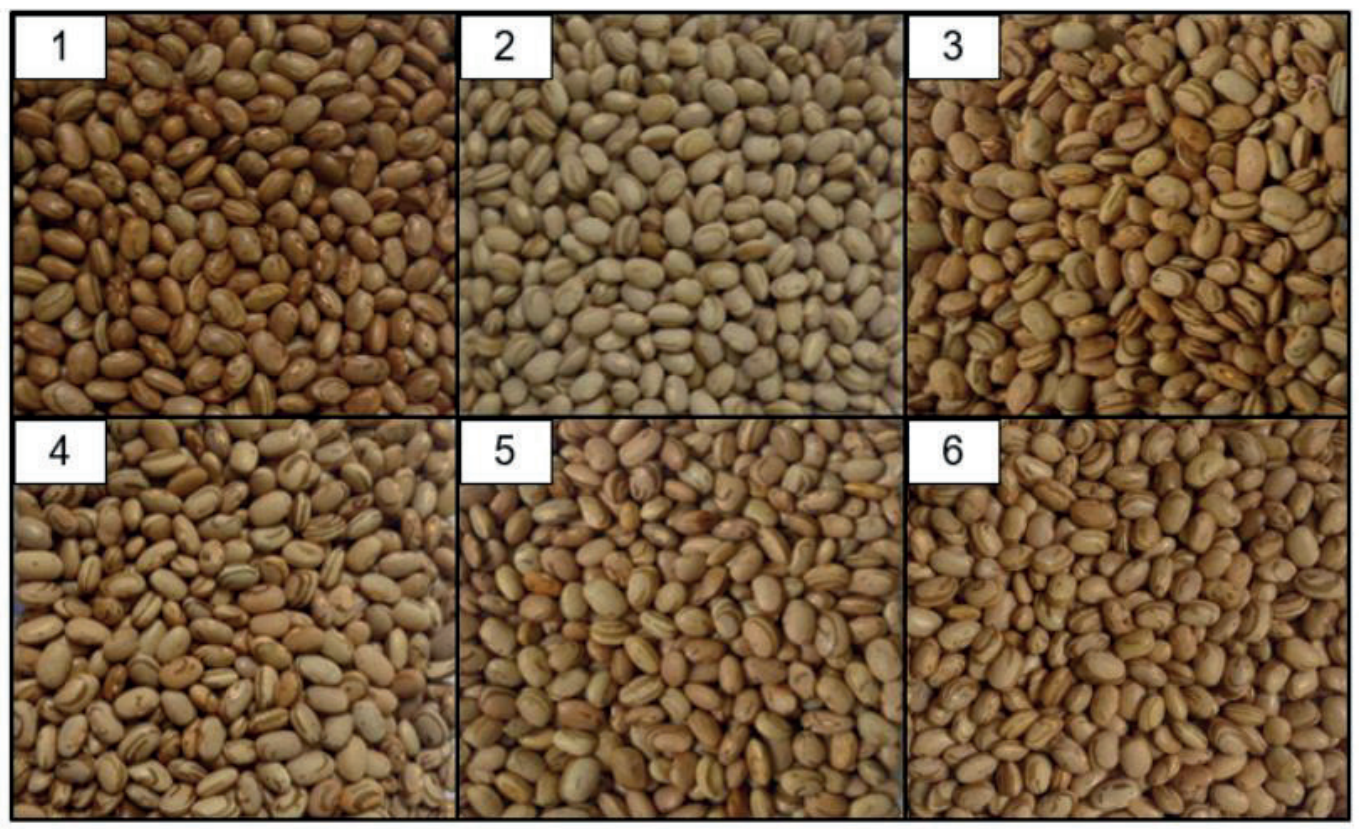

A multiple-choice questionnaire was developed to identify which visual quality traits define consumer preference for a given commercial brand of carioca bean. The analysis was conducted in the Quality Laboratory of the Federal University of Santa Maria (UFSM), which is equipped with fluorescent lights and individual sensory booths. People linked to UFSM (students, teachers and administrative clerks) and people external to UFSM were invited to participate. The 52 survey participants motivated to participate in the research had time available and were frequent consumers of common bean.

The survey group consisted of people between 17 and 88 years old with different social classes, educational levels, genders and ethnicities; therefore, the sample was representative of the population that consumes carioca beans in Santa Maria, Rio Grande do Sul, Brazil. For each of the five questions, each participant chose the option that best represented his preference. The responses to each question were used to plot frequency distributions.

The evaluations of the technological, cooking and nutritional quality traits of the commercial brands of carioca beans were conducted in a completely randomized design with four replications. The colour of the grains was determined with a portable colorimeter (CR 410, Konica Minolta, Osaka, Japan). The values were obtained by the numerical system of the International Commission on 
Illumination (CIE). The $\mathrm{L}^{*}$ parameter defines the lightness of the sample and varies from 0 (black) to 100 (white); the component $\mathrm{a}^{*}$ characterizes the variation of the green and red shades, ranging from - 60 (dark green) to +60 (dark red); and the component $b^{*}$ measures the variation of the blue and yellow shades, ranging from - 60 (dark blue) to +60 (dark yellow) (BERNARDO, 2010). For this purpose, one $50 \mathrm{~g}$ grain sample was set on a Petri dish $6.0 \mathrm{~cm}$ in diameter and $1.5 \mathrm{~cm}$ in height, covering it completely. The colorimeter head was placed over the grains, and three readings were taken at different positions of the Petri dish for each grain sample.

The mass of 100 grains was measured at $13 \%$ average moisture. Then, 10 grains were randomly sampled in each replication to determine the grain length, width and thickness, which were measured with a digital calipre. The grain shape was obtained by the length to width ratio, and the degree of flatness of the beans was assessed by the thickness to width ratio, as described by Puerta Romero (1961).

Samples of 25 grains were weighed before being soaked in distilled water (1:5 ratio) for eight hours at ambient temperature $\left(20{ }^{\circ} \mathrm{C} \pm 2{ }^{\circ} \mathrm{C}\right)$. After the maceration period, the percentage of the grains that absorbed or did not absorb water, normal and hard grains, respectively, was obtained. Water uptake was determined by the difference in grain weight before and after maceration and expressed as a \%. Bean cooking time was assessed in a Mattson cooker (Embrapa Instrumentação, São Carlos, Brazil) with 25 pegs, as described by Ribeiro et al. (2014). The mean falling time of the first 13 pegs was considered the cooking time of each sample.

Raw grain samples of $50 \mathrm{~g}$ were ground in an analytical micro-mill to obtain particles smaller than $1 \mathrm{~mm}$ in diameter, not sieved, for the determination of the concentrations of crude protein (protein) and minerals. The protein analysis was carried out according to the Kjeldahl method, as described by the Association of Official Analytical Chemists, number 960.52 (AOAC, 1995). The total nitrogen value obtained was multiplied by 6.25 for the conversion to protein. The mineral concentration was determined by nitric-perchloric acid digestion, as described by Jost et al. (2013). The potassium concentration was obtained by a flame photometer (DM-62, Digicrom Analítica Ltda, São Paulo, Brazil), and the phosphorus concentration was read using an optical emission spectrophotometer (AA-7000, Shimadzu, São Paulo, Brazil). Concentrations of calcium, magnesium, iron, zinc and copper were determined by an atomic absorption spectrophotometer (AAS, Perkin Elmer AAnalyst 200, Waltham, USA).

The data obtained were subjected to analysis of variance. For the traits evaluated as a percentage (normal grains, hard grains and water uptake), the transformation $\sqrt{\mathrm{x}+0.5}$, where $\mathrm{x}$ is the trait value, was used. Comparison of the mean values between the bean samples was made using the Scott-Knott test $(p$ value $=0.05)$. The experimental precision was assessed by the coefficient of experimental variation $(\mathrm{CV})$ that was obtained by the $\mathrm{CV}=\frac{100 \sqrt{\mathrm{EMS}}}{\widehat{\mathrm{m}}}$ formula, where EMS corresponds to the error mean square, and $\hat{\mathrm{m}}$ is the experimental overall mean. The selective accuracy (SA) was obtained by the following expression: $\mathrm{SA}=\sqrt{1-\frac{1}{\mathrm{Fc}}}$ for $F \mathrm{c} \geq 1$ and $\mathrm{SA}=0$ for $\mathrm{Fc}<1$, where $\mathrm{Fc}$ the F-test value for genotype (RESENDE; DUARTE, 2007).

The selection index ( $\bar{Z}$ index) was used to identify the best commercial brand of carioca beans for their technological, cooking and nutritional quality traits. The $\bar{Z}$ index was estimated as described by Mendes et al. (2009). A constant equal to three was added to the mean $\bar{Z}$ index of the traits present in the four replications to avoid negative values. The contribution of each standardized trait in the $\bar{Z}$ index was shown in charts. The charts were made in Microsoft Office Excel spreadsheets, and the statistical analyses were carried out using Genes software (CRUZ, 2016). 


\section{Results and Discussion}

Visual quality traits that determine the consumer choice of carioca beans

Among the 52 people surveyed who participated in the present study, 20 eat common bean regularly, five to six days per week (Figure 2A). Another 15 participants reported eating common bean three to four days per week, and three participants consumed common bean in at least one daily meal. Therefore, $73.08 \%$ of the participants had the habit of eating common bean three to seven days per week, which was very healthy. Common bean is a food that contains high-quality protein (RIBEIRO et al., 2007) and is an excellent source of minerals (DI BELLA et al., 2016; PINHEIRO et al., 2010; RIBEIRO et al., 2013a, b; SILVA et al., 2012; STECKLING et al., 2017). These traits ensure the functional properties of common beans, and various health benefits have been associated with the regular consumption of this food (CÂMARA et al., 2013; MESSINA, 2014).

Figure 2. Representation of the options chosen by the survey participants in the questionnaire used to determine the consumer preference of carioca beans.

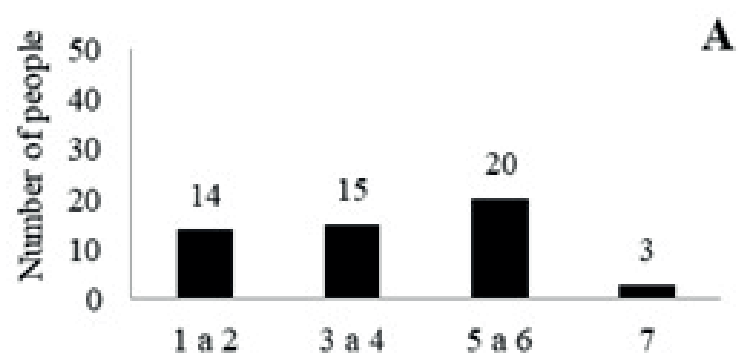

Number of days of the week eating beans

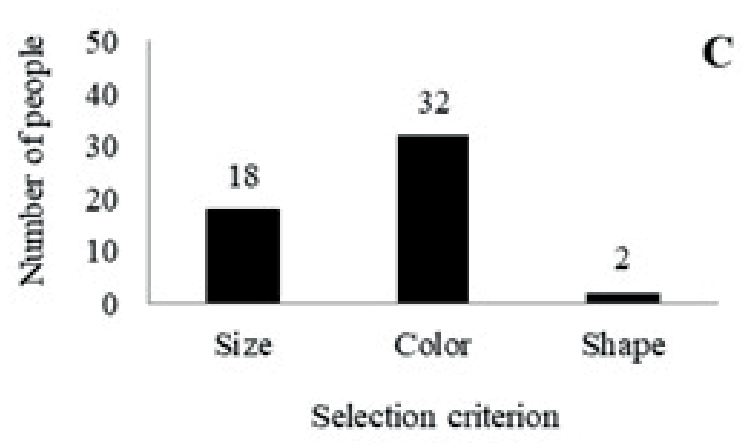

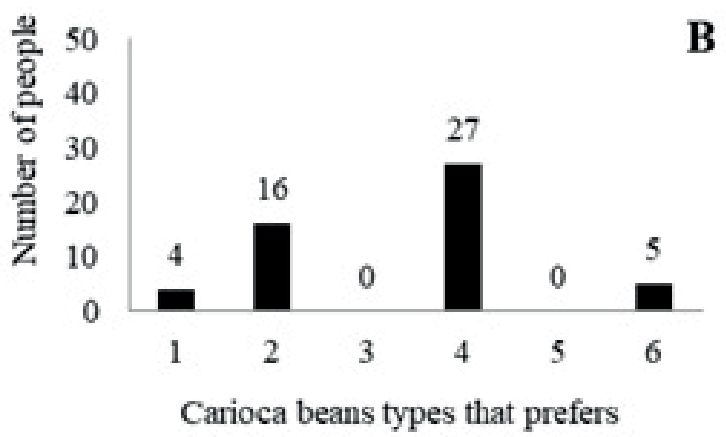

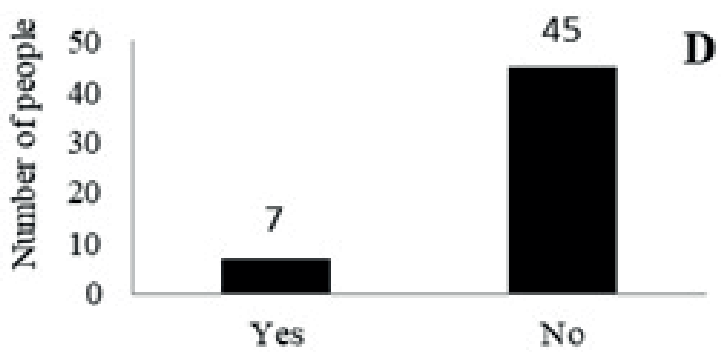

You observe nutritional facts when buying beans

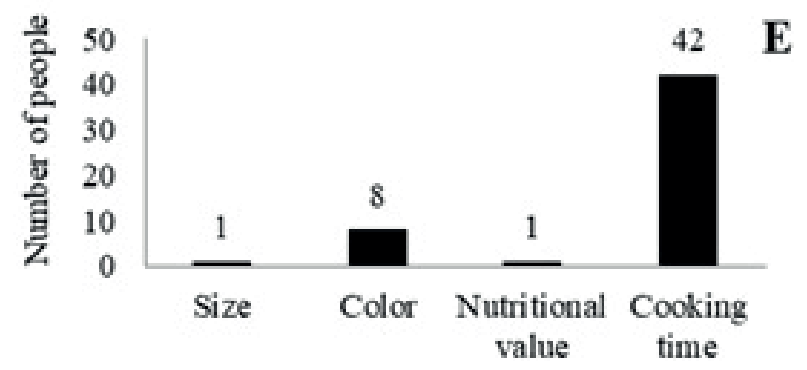

By the same price, choice is based on 
Among the six commercial brands of carioca beans included in the study, sample 4 was the one preferred by most of the participants (27) (Figure 2B). Sample 2 was second in the preference rank of the participants followed by samples 6 and 1 . Samples 3 and 5 were not selected by any of the participants. The best understanding of which grain traits of carioca beans define consumer choice is vitally important for bean growers, traders and breeders. The development and production of carioca bean cultivars with grain traits that meet the consumer preference represent technological advances.

The participants initially chose the carioca beans by grain colour $(61.54 \%)$ followed by size (34.61\%) and shape (3.85\%) (Figure 2C). The colour and size of the carioca bean grains were the first visual quality traits evaluated by consumers and were decisive in product choice, which corroborates previous results described by Gathu et al. (2012). Carioca beans with lighter colour grains are associated with freshly harvested beans, which require less cooking time (RIBEIRO et al., 2008), and for this reason, are better accepted by consumers. The grain size, in turn, is associated with high cooking yield (CARBONELL et al., 2010). Larger grain sizes usually exhibit more expansion after water uptake and cooking, which results in a larger volume of cooked beans, a characteristic that is highly appreciated by consumers.

The fourth question of the questionnaire aimed to assess whether the nutritional information described on the package label was considered by consumers when choosing a given commercial brand of carioca beans. Forty-five participants, corresponding to $86.54 \%$ of the total survey participants, did not read the nutritional information displayed on the packages when they bought beans (Figure 2D). Therefore, it is very important to evaluate whether consumers do not know the nutritional value of beans, if there is a lack of marketing appeal or if there is a lack of information highlighted on the package label. Common beans have high concentrations of protein and minerals; however, great content variability has been observed among bean genotypes, depending on the growing environment and the genotype $x$ environment interaction (MAZIERO et al., 2015; PEREIRA et al., 2017; STECKLING et al., 2017). For this reason, information regarding the identification of the common bean cultivar and its production origin should be included in the package label to allow for traceability and the meeting of quality expectations. These factors affect the nutritional value of the common bean and, therefore, should be observed by consumers.

Another important criterion for consumer choice of the common bean is price. If the price of different commercial brands of carioca beans is held constant, $80.77 \%$ of the survey participants would consider cooking time as the determinant factor for bean choice (Figure 2E). This is justified by a demand for foods that require less cooking time and less expenditure on cooking gas to prepare meals. Common bean cultivars that cook in less than 25 min are considered fast cooking (SANTOS et al., 2016; STECKLING et al., 2017) and meet the demand of consumers who seek practicality and economy in the preparation of their meals.

In the present study, two sensory quality traits determined the evaluator choice of the carioca beans: grain colour and size. These traits are visually evaluated by consumers. However, it is necessary to investigate whether consumers, when choosing a commercial brand of carioca bean by its visual quality traits, are buying fresh beans, those with fast cooking times and those with higher nutritional value.

Technological and cooking quality traits of carioca beans

In the analysis of variance, a significant effect of treatment regarding all technological and cooking quality traits was observed, indicating that the commercial brands of carioca beans had differences for the traits evaluated. This is justified by the 
genetic variability among common bean genotypes, the growing environment and the genotype $\mathrm{x}$ environment interaction, as previously observed by Ribeiro et al. (2014) for L* values, the mass of 100 grains and cooking time and by Santos et al. (2016) regarding the mass of 100 grains, grain size, shape, degree of flatness, water uptake and cooking time of beans.

The CV values ranged from 1.18 ( $\mathrm{L}^{*}$ value) to $36.34 \%$ (hard grains) (Table 1). Similar CV values were obtained by Ribeiro et al. (2014) and Santos et al. (2016) of the technological and cooking quality traits of beans. However, Silva et al. (2016) found a lower CV value when they evaluated hard grains in common bean genotypes. In the present study, hard grains were observed in three samples $(4,5$ and 6), which contributed to the high CV value found for this trait. When the experimental precision was assessed by SA, values higher than $85.26 \%$ were obtained, indicating high experimental precision in the evaluation of the technological and cooking quality traits of carioca beans, considering the classes defined by Resende and Duarte (2007).

The colours of the carioca beans of the different brands were assessed. Sample 2 had the lightest grains $\left(\mathrm{L}^{*}=56.41\right)$, with slightly shades of red (lower $\mathrm{a}^{*}$ value) and yellow (lower $\mathrm{b}^{*}$ value) (Table 1). Carioca bean cultivars with lighter grains $\left(\mathrm{L}^{*}\right.$ $\geq 55.00)$ are associated with fresh and fast cooking grains (RIBEIRO et al., 2008) and are therefore better accepted by consumers.

Samples 3, 4, 5 and 6 did not differ in their $\mathrm{L}^{*}$ and $a^{*}$ values but showed variability in the yellow shade ( $b^{*}$ value). Similar $L^{*}$ values were observed by Oliveira et al. (2011) in freshly harvested carioca beans of the Carioca $\left(\mathrm{L}^{*}=52.26\right)$ and Pérola $\left(\mathrm{L}^{*}=\right.$ 53.86) cultivars. These two carioca bean cultivars are widely accepted by Brazilian consumers due to the high lightness of recently harvested grains. Thus, all commercial brands of carioca beans evaluated in this study had an $\mathrm{L}^{*}$ value that characterizes lighter colour grains $\left(\mathrm{L}^{*} \geq 52.00\right)$ except for sample 1 , which had darker colour grains $\left(\mathrm{L}^{*}=48.06\right)$. All carioca bean samples also showed a slightly red shade, i.e., an $\mathrm{a}^{*}$ value $\leq 7.00$, which is the optimal standard for carioca beans (ARNS et al., 2018), except for sample 1 . However, the slightly yellow shade ( $\left.b^{*} \leq 16.00\right)$, as recommended by Arns et al. (2018) as a standard for carioca beans, was only verified in sample 2.

When common bean is sold in supermarkets, it is stored at room temperature. In this condition, the carioca bean cultivars exhibit a decrease in the $L^{*}$ value and an increase in the $a^{*}$ and $b^{*}$ values during storage (RANI et al., 2013; SIQUEIRA et al., 2014, 2016a). Therefore, the storage of carioca beans at room temperature causes grain darkening. In the present study, the grains of sample 1 had the lowest $\mathrm{L}^{*}$ value and the highest $\mathrm{a}^{*}$ value, indicating that it is the sample that was on the shelves for the longest time or is the most susceptible to darkening. Carioca bean cultivars that have grain darkening can be rejected by consumers because they associate darkened grains with longer cooking times.

The carioca bean grains of samples 1,3, 4 and $5 \mathrm{had}$ a mass of 100 grains over $25 \mathrm{~g}$. In addition, all commercial brands of carioca beans evaluated had an elliptical shape and a semi-full grain flatness degree except sample 2, which had a spherical shape and a full flatness grains. In Brazil, consumers of carioca beans prefer medium-sized grains, i.e., those with a mass of 100 grains between 25 and $30 \mathrm{~g}$, with an elliptical shape and semi-full flatness because they associate these traits with higher cooking yield (CARBONELL et al., 2010). These grain traits have been considered in the selection of new carioca bean cultivars by breeding programmes (ARNS et al., 2018; SANTOS et al., 2016; SILVA et al., 2016). In the present study, all commercial brands of carioca beans had the standards for grain size, shape and flatness degree for carioca beans proposed by Carbonell et al. (2010) except for samples 2 and 6 .

The presence of hard grains, i.e., grains that did not absorb water after soaking, was found in samples 4, 5 and 6. Most of the carioca bean cultivars and 
the new lines developed by breeding programmes in Brazil do not have hard grains, or the percentage of hard grains observed in freshly harvested beans is very low (MINGOTTE et al., 2013; OLIVEIRA et al., 2011; SILVA et al., 2016). This is because the occurrence of hard grains is associated with decreased cooking quality because the bean grains become more resistant to softening during cooking, and this was associated with higher activity of the peroxidase enzyme (SIQUEIRA et al., 2016b).

Table 1. Values, mean, coefficient of variation (CV\%) and selective accuracy (SA\%) for lightness (L*), component a* $\left(a^{*}\right)$, component $b^{*}\left(b^{*}\right)$, mass of 100 grains (mass), grain length (length), width (width), thickness (thickness), shape (shape), degree of flatness (flatness), normal grains (normal), hard grains (hard), water uptake (uptake), cooking time (cooking), and concentrations of protein, potassium $(\mathrm{K})$, phosphorus $(\mathrm{P})$, calcium $(\mathrm{Ca})$, magnesium $(\mathrm{Mg})$, iron $(\mathrm{Fe})$, zinc $(\mathrm{Zn})$ and copper $(\mathrm{Cu})$ in six different commercial brands of carioca beans.

\begin{tabular}{|c|c|c|c|c|c|c|c|c|c|c|c|c|c|c|}
\hline \multirow{2}{*}{$\begin{array}{c}\text { Brands } \\
\text { Sample } 1\end{array}$} & \multicolumn{2}{|l|}{$\mathrm{L}^{*}$} & \multicolumn{2}{|l|}{$\mathrm{a}^{*}$} & \multicolumn{2}{|l|}{$\mathrm{b}^{*}$} & \multicolumn{2}{|c|}{ Mass (g) } & \multicolumn{2}{|c|}{ Length (mm) } & \multicolumn{2}{|c|}{ Width (mm) } & \multicolumn{2}{|c|}{ Thickness (mm) } \\
\hline & 48.06 & $\mathrm{c}^{1}$ & 7.18 & $\mathrm{a}$ & 16.27 & $\mathrm{c}$ & 26.70 & $\mathrm{a}$ & 9.82 & $\mathrm{~d}$ & 6.53 & $\mathrm{c}$ & 5.19 & $\mathrm{a}$ \\
\hline Sample 2 & 56.41 & $\mathrm{a}$ & 4.04 & $\mathrm{c}$ & 13.83 & $\mathrm{~d}$ & 23.82 & $\mathrm{c}$ & 8.94 & e & 6.30 & d & 5.08 & $\mathrm{~b}$ \\
\hline Sample 3 & 52.68 & $\mathrm{~b}$ & 6.42 & $\mathrm{~b}$ & 17.49 & $\mathrm{~b}$ & 25.10 & $\mathrm{~b}$ & 10.36 & $\mathrm{~b}$ & 6.69 & $\mathrm{~b}$ & 4.92 & $\mathrm{~b}$ \\
\hline Sample 4 & 53.30 & $\mathrm{~b}$ & 6.20 & $\mathrm{~b}$ & 16.87 & $\mathrm{c}$ & 27.52 & $\mathrm{a}$ & 10.58 & $\mathrm{a}$ & 6.79 & $\mathrm{~b}$ & 5.03 & $\mathrm{~b}$ \\
\hline Sample 5 & 52.91 & $\mathrm{~b}$ & 6.03 & $\mathrm{~b}$ & 16.62 & $\mathrm{c}$ & 27.60 & $\mathrm{a}$ & 10.74 & $\mathrm{a}$ & 7.08 & $\mathrm{a}$ & 5.32 & $\mathrm{a}$ \\
\hline Sample 6 & 52.87 & $\mathrm{~b}$ & 6.28 & $\mathrm{~b}$ & 18.12 & $\mathrm{a}$ & 22.62 & $\mathrm{c}$ & 10.07 & $\mathrm{c}$ & 6.49 & $\mathrm{c}$ & 5.11 & $\mathrm{~b}$ \\
\hline Mean & 52.70 & & 6.02 & & 16.53 & & 25.56 & & 10.09 & & 6.65 & & 5.11 & \\
\hline $\mathrm{CV} \%$ & 1.18 & & 3.46 & & 2.36 & & 3.36 & & 1.63 & & 2.06 & & 2.68 & \\
\hline $\mathrm{SA} \%$ & 99.32 & & 99.51 & & 99.12 & & 97.80 & & 99.21 & & 96.76 & & 86.78 & \\
\hline Brands & \multicolumn{2}{|l|}{ Shape } & \multicolumn{2}{|c|}{ Flatness } & \multicolumn{2}{|c|}{ Normal (\%) } & \multicolumn{2}{|c|}{ Hard (\%) } & \multicolumn{2}{|c|}{ Uptake (\%) } & \multicolumn{2}{|c|}{ Cooking (min:s) } & \multicolumn{2}{|c|}{ Protein $(\%)$} \\
\hline Sample 1 & \multicolumn{2}{|c|}{ Elliptical } & \multicolumn{2}{|c|}{ Semi-Full } & 100.00 & $\mathrm{a}$ & 0.00 & $\mathrm{c}$ & 85.14 & $\mathrm{~b}$ & $28: 34$ & $\mathrm{e}$ & 20.56 & $\mathrm{~b}$ \\
\hline Sample 2 & \multicolumn{2}{|c|}{ Spherical } & \multicolumn{2}{|c|}{ Full } & 100.00 & $\mathrm{a}$ & 0.00 & $\mathrm{c}$ & 89.83 & $\mathrm{a}$ & 13:01 & $\mathrm{a}$ & 22.09 & $\mathrm{a}$ \\
\hline Sample 3 & \multicolumn{2}{|c|}{ Elliptical } & \multicolumn{2}{|c|}{ Semi-Full } & 100.00 & $\mathrm{a}$ & 0.00 & $\mathrm{c}$ & 94.59 & $\mathrm{a}$ & $19: 28$ & $\mathrm{c}$ & 21.70 & $\mathrm{a}$ \\
\hline Sample 4 & \multicolumn{2}{|c|}{ Elliptical } & \multicolumn{2}{|c|}{ Semi-Full } & 95.00 & $\mathrm{a}$ & 5.00 & $\mathrm{~b}$ & 85.58 & $\mathrm{~b}$ & $15: 25$ & $\mathrm{~b}$ & 22.45 & $\mathrm{a}$ \\
\hline Sample 5 & \multicolumn{2}{|c|}{ Elliptical } & \multicolumn{2}{|c|}{ Semi-Full } & 88.00 & $\mathrm{~b}$ & 12.00 & $\mathrm{a}$ & 84.37 & $\mathrm{~b}$ & $21: 13$ & $\mathrm{~d}$ & 22.55 & $\mathrm{a}$ \\
\hline Sample 6 & \multicolumn{2}{|c|}{ Elliptical } & \multicolumn{2}{|c|}{ Semi-Full } & 90.00 & $\mathrm{~b}$ & 10.00 & $\mathrm{a}$ & 89.29 & $\mathrm{a}$ & $12: 46$ & $\mathrm{a}$ & 17.98 & $\mathrm{c}$ \\
\hline Mean & - & & - & & 95.50 & & 4.50 & & 88.13 & & $18: 25$ & & 21.22 & \\
\hline $\mathrm{CV} \%$ & 1.51 & & 2.53 & & 2.01 & & 36.34 & & 2.26 & & 5.98 & & 2.63 & \\
\hline $\mathrm{SA} \%$ & 97.49 & & 94.78 & & 93.49 & & 96.68 & & 85.26 & & 99.58 & & 98.70 & \\
\hline Brands & $\mathrm{K}(\mathrm{g} \mathrm{kg}$ & & $\mathrm{P}\left(\mathrm{g} \mathrm{k}_{\mathrm{g}}\right.$ & & $\mathrm{Ca}(\mathrm{g} \mathrm{k}$ & & $\mathrm{Mg}(\mathrm{g}$ & & $\mathrm{Fe}(\mathrm{m}$ & $\mathrm{g}^{-1)}$ & $\mathrm{Zn}($ & $\mathrm{kg}^{-1)}$ & $\mathrm{Cu}(\mathrm{r}$ & \\
\hline Sample 1 & 12.28 & $\mathrm{a}$ & 6.19 & $\mathrm{~b}$ & 1.22 & $\mathrm{c}$ & 1.47 & ns & 87.60 & $\mathrm{a}$ & 28.57 & $\mathrm{~b}$ & 10.65 & $\mathrm{c}$ \\
\hline Sample 2 & 12.39 & $\mathrm{a}$ & 7.08 & $\mathrm{a}$ & 1.25 & $\mathrm{c}$ & 1.49 & & 67.48 & $\mathrm{c}$ & 28.17 & $\mathrm{~b}$ & 9.10 & $\mathrm{~d}$ \\
\hline Sample 3 & 12.49 & $\mathrm{a}$ & 6.26 & $\mathrm{~b}$ & 1.65 & $\mathrm{a}$ & 1.45 & & 68.48 & $\mathrm{c}$ & 28.10 & $\mathrm{~b}$ & 10.95 & $\mathrm{c}$ \\
\hline Sample 4 & 12.44 & $\mathrm{a}$ & 7.29 & $\mathrm{a}$ & 1.46 & $\mathrm{~b}$ & 1.41 & & 77.50 & $\mathrm{~b}$ & 33.80 & $\mathrm{a}$ & 13.22 & $\mathrm{a}$ \\
\hline Sample 5 & 10.66 & $\mathrm{c}$ & 5.91 & $\mathrm{~b}$ & 1.73 & $\mathrm{a}$ & 1.49 & & 82.38 & $\mathrm{~b}$ & 21.52 & $\mathrm{c}$ & 11.62 & $\mathrm{~b}$ \\
\hline Sample 6 & 11.60 & $\mathrm{~b}$ & 6.01 & $\mathrm{~b}$ & 1.18 & $\mathrm{c}$ & 1.42 & & 79.80 & $\mathrm{~b}$ & 34.67 & $\mathrm{a}$ & 8.90 & $\mathrm{~d}$ \\
\hline Mean & 11.98 & & 6.46 & & 1.41 & & 1.45 & & 77.21 & & 29.14 & & 10.74 & \\
\hline $\mathrm{CV} \%$ & 4.75 & & 10.33 & & 8.74 & & 8.71 & & 5.71 & & 9.80 & & 4.88 & \\
\hline $\mathrm{SA} \%$ & 91.98 & & 81.85 & & 96.52 & & 0.00 & & 96.03 & & 95.37 & & 98.68 & \\
\hline
\end{tabular}

${ }^{1}$ Means followed by same letter in a column do not differ from each other by Scott-Knott's test at $5 \%$ probability. ns $=$ nonsignificant. 
Water uptake varied from 84.37 (sample 5) to $94.59 \%$ (sample 3). A similar range of variation was observed in the fresh grains of the carioca bean genotypes (OLIVEIRA et al., 2011; SANTOS et al., 2016) and in carioca bean grains bought in the supermarkets located in Cascavel, Paraná, Brazil (ZIMMERMANN et al., 2009) after soaking them in distilled water for 8 and $10 \mathrm{~h}$, respectively.

The fastest cooking time was observed for sample 6 (12 min and $46 \mathrm{~s}$ ), and the longest cooking time was observed for sample 1 (28 min and 34 s). Freshly harvested carioca beans usually have a cooking time less than 25 min (MINGOTTE et al., 2013; OLIVEIRA et al., 2011; SANTOS et al., 2016; STECKLING et al., 2017), which is considered fast by Santos et al. (2016). In the present study, all commercial brands of carioca beans had fast cooking times except sample 1 . Sample 1 had a longer cooking time (28 min and $34 \mathrm{~s}$ ) and darker colour grains $\left(\mathrm{L}^{*}=48.06\right)$ compared to the other commercial brands of carioca beans. Therefore, carioca bean grains with a dark colour will require a longer cooking time to attain the softness considered ideal for consumption and for this reason might be rejected by consumers.

\section{Nutritional quality traits of carioca beans}

The commercial brands of carioca beans showed differences in all nutritional quality traits except for the magnesium concentration in the grains. Similarly, it was observed that the carioca bean genotypes showed genetic variability for protein (BARROS; PRUDENCIO, 2016; MINGOTTE et al., 2013; PEREIRA et al., 2017; SILVA et al., 2012) and mineral concentrations (JOST et al., 2013; MAZIERO et al., 2015; RIBEIRO et al., 2013a; SILVA et al., 2012; STECKLING et al., 2017). The protein and mineral concentrations in carioca beans can also vary according to the growing environment and the genotype $\mathrm{x}$ environment interaction (PEREIRA et al., 2017; RIBEIRO et al., 2013a; STECKLING et al., 2017).
Low $\mathrm{CV}$ values $(\mathrm{CV} \leq 10.33 \%)$ and high SA values $(\mathrm{SA} \geq 81.85 \%$ ) were obtained for all nutritional quality traits except for magnesium concentration, in which the SA obtained was null. Similar values of CV were observed for protein (MINGOTTE et al., 2013; PEREIRA et al., 2017) and mineral concentrations (MAZIERO et al., 2015; STECKLING et al., 2017) in common bean genotypes. The lower CV results indicate higher experimental precision in the evaluation of the protein and mineral concentrations in carioca beans. However, when considering SA, a high experimental precision ( $\mathrm{SA} \geq 70.00 \%$ ) was observed for the concentrations of protein, potassium, phosphorus, calcium, iron, zinc and copper, and a low experimental precision ( $\mathrm{SA} \leq 40.00 \%$ ) was obtained for magnesium concentration, according to the classes defined by Resende and Duarte (2007). For magnesium concentration in the grains, there was no difference among the commercial brands of carioca beans by the F-test, and as $\mathrm{Fc}<1$, the SA was null.

The protein concentration varied from 17.98 (sample 6) to $22.55 \%$ (sample 5). Similar values of protein concentration were observed in freshly harvested grains of carioca bean genotypes (MINGOTTE et al., 2013; PEREIRA et al., 2017). However, Barros and Prudencio (2016) reported that protein concentrations as high as $25 \%$ can be found in some carioca bean cultivars. These results indicate that the protein concentration in beans may vary with the genotype and growing environment, especially with the organic matter content in the soil. In addition, previous studies have shown that common bean has high quality protein due to the composition of essential and non-essential amino acids found in the grains (RIBEIRO et al., 2007).

Carioca beans had high concentrations of potassium, followed by phosphorus, magnesium, calcium, iron, zinc and copper. A similar proportion of minerals has also been observed in other grain types of common bean grown in Brazil (RIBEIRO et al., 2013a; SILVA et al., 2012; STECKLING et al., 
2017), Portugal (PINHEIRO et al., 2010) and other countries (DI BELLA et al., 2016). These previous studies also showed genetic variability in mineral concentration among common bean genotypes of the same grain type.

Commercial brands of carioca beans showed variations in the concentrations of macro-minerals, potassium, phosphorus and calcium. Samples 1, 2, 3 and 4 had high potassium concentrations, as previously defined by Steckling et al. (2017) for common bean as $>12.00 \mathrm{~g} \mathrm{~kg}^{-1}$ of dry matter - DM. Samples 2 and 4 showed the highest phosphorus concentration. However, all carioca bean samples exhibited high phosphorus concentrations $(>5.00 \mathrm{~g}$ $\mathrm{kg}^{-1} \mathrm{DM}$ ) according to the classification proposed by Steckling et al. (2017). Samples 3, 4 and 5 presented high calcium concentrations in the grains $(>1.40$ $\mathrm{g} \mathrm{kg}^{-1} \mathrm{DM}$ ) according to the classes established for common beans by Ribeiro et al. (2013b). Silva et al. (2012) found the following mean values: phosphorus $=5.30 \mathrm{~g} \mathrm{~kg}^{-1} \mathrm{DM}$, potassium $=18.10 \mathrm{~g}$ $\mathrm{kg}^{-1} \mathrm{DM}$, and calcium $=1.40 \mathrm{~g} \mathrm{~kg}^{-1} \mathrm{DM}$ in 53 carioca bean genotypes.

For the micro-mineral concentrations, differences were also observed among the commercial brands of carioca beans. Sample 1 presented the highest iron concentration (87.60 mg kg-1 DM). However, none of the commercial brands of carioca beans had a high iron concentration, as defined previously by Ribeiro et al. (2013b) as $>95.00 \mathrm{mg} \mathrm{kg}^{-1} \mathrm{DM}$. For zinc, two samples (4 and 6) of carioca beans showed high concentrations of this micro-mineral, i.e., values higher than $31 \mathrm{mg} \mathrm{kg}^{-1} \mathrm{DM}$ according to Tryphone and Nchimbi-Msolla (2010). Sample 4 presented the highest copper concentration (13.22 $\left.\mathrm{mg} \mathrm{kg}{ }^{-1} \mathrm{DM}\right)$ in the grains, exceeding the other carioca bean samples that were evaluated. This value of copper was higher than that observed in common bean genotypes cultivated in Brazil (RIBEIRO et al., 2013a; STECKLING et al., 2017) and similar to the highest values found in common bean genotypes cultivated in Portugal (PINHEIRO et al., 2010). Thus, copper concentrations higher than $13.00 \mathrm{mg} \mathrm{kg}^{-1} \mathrm{DM}$ can be considered high for carioca bean grains.

Among the commercial brands of carioca beans evaluated, there were samples that exhibited higher concentrations of one or more minerals due to different reasons linked not only to genetics but also to environmental interaction. These minerals can help prevent various diseases. For example, potassium reduces cardiovascular diseases and prevents the development of diabetes (HE; MACGREGOR, 2008); phosphorus diminishes symptoms of fatigue, anxiety and bone pain (MARTÍNEZ-BALLESTA et al., 2010); calcium prevents the development of osteoporosis, osteomalacia and rickets (CZAJKANARINS, 1998); zinc acts in the immune system and in the treatment of dermatitis (GIBSON, 2012); and copper acts in the iron mobilization for haemoglobin synthesis (FRANCO, 2005). Therefore, the consumption of foods that are nutritionally rich has benefits for consumers' health. In the present study, sample 4 presented high concentrations of protein, potassium, phosphorus, calcium, zinc and copper. Therefore, sample 4 has high nutritional quality.

\section{Combined selection for technological, cooking and} nutritional quality traits in carioca beans

Sample 4 was the preference of $51.92 \%$ of the participants (Figure 2B), and their choice was defined by colour and grain size (Figure 2C). In the selection index analysis, it was observed that sample 4 showed the highest $\bar{Z}$ index for the $\mathrm{L}^{*}$ value, mass of 100 grains, length and width grains, concentrations of protein, potassium, phosphorus, calcium, zinc and copper, and the lowest $\bar{Z}$ index for water uptake and cooking time (Figure 3 ). Thus, sample 4 has lighter colour grains, medium-sized beans, is nutritionally richer and has fast cooking grains, traits which are desirable for the carioca bean market. The use of the $\bar{Z}$ index enabled the selection of common bean genotypes that simultaneously present high grain yield, high mineral concentration in the grains and reduced cooking time (RIBEIRO et al., 2013a). 
Figure 3. Representation of index for lightness $\left(\mathrm{L}^{*}\right)$, component $\mathrm{a}^{*}\left(\mathrm{a}^{*}\right)$, component $\mathrm{b}^{*}\left(\mathrm{~b}^{*}\right)$, mass of 100 grains (mass, g), length $(\mathrm{mm})$, width $(\mathrm{mm})$, thickness $(\mathrm{mm})$, normal grains (normal, \%), water uptake (uptake, \%), cooking time (cooking, min:s), and concentrations of protein (\%), potassium (K, $\mathrm{g} \mathrm{kg}^{-1}$ of dry matter - DM), phosphorus (P, $\mathrm{g}$ $\left.\mathrm{kg}^{-1} \mathrm{DM}\right)$, calcium (Ca, $\left.\mathrm{g} \mathrm{kg}^{-1} \mathrm{DM}\right)$, iron (Fe, $\left.\mathrm{mg} \mathrm{kg}^{-1} \mathrm{DM}\right)$, zinc ( $\left.\mathrm{Zn}, \mathrm{mg} \mathrm{kg}^{-1} \mathrm{DM}\right)$, and copper $\left(\mathrm{Cu}, \mathrm{mg} \mathrm{kg}^{-1} \mathrm{DM}\right)$ in six different commercial brand of carioca beans.
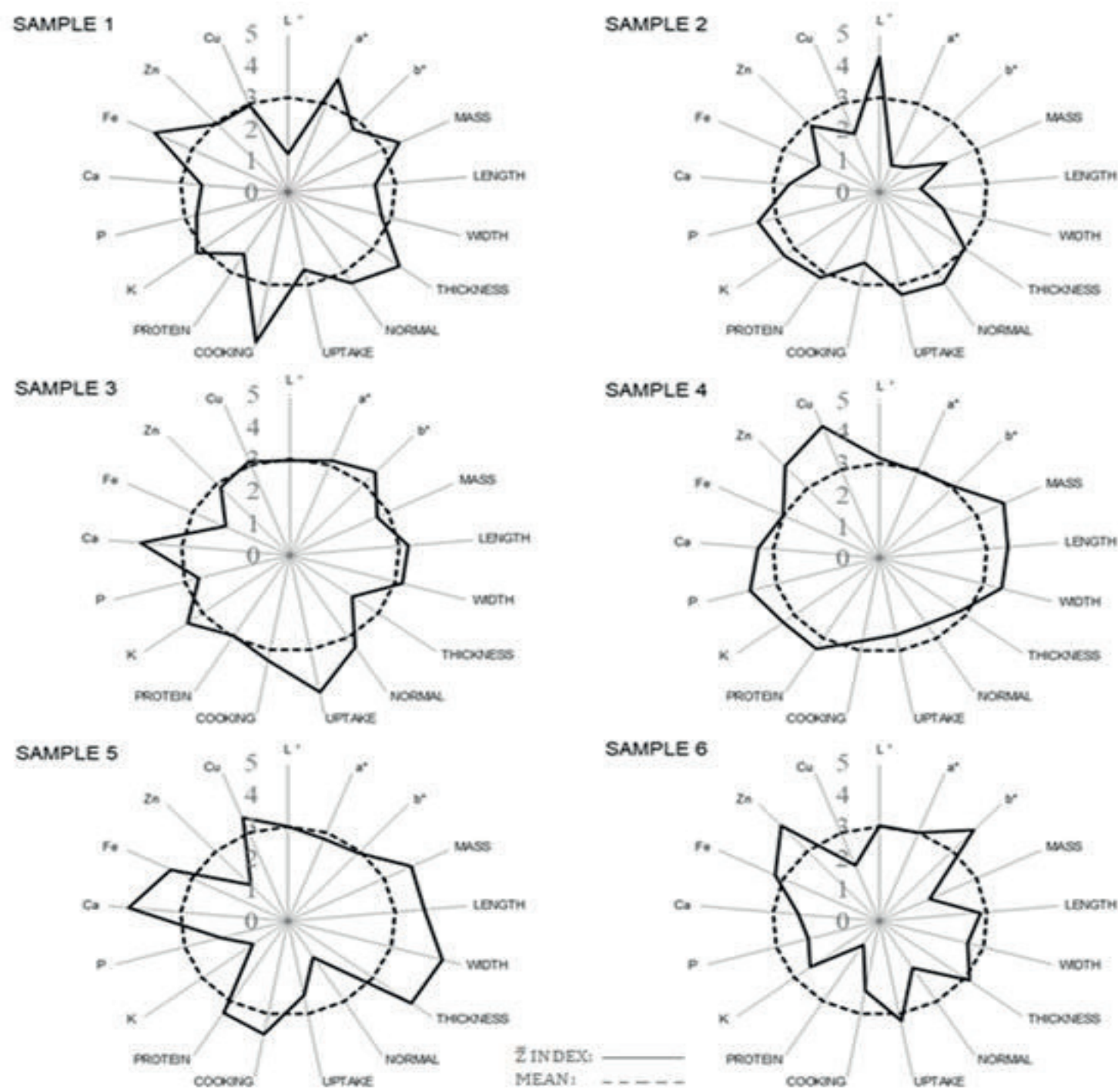

SAMPLE 4

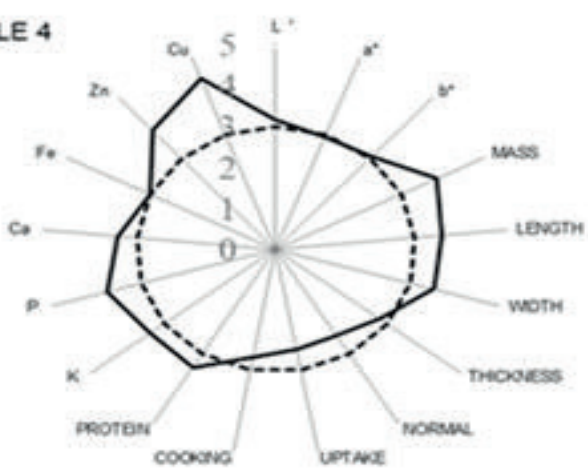

SAMPLE 6

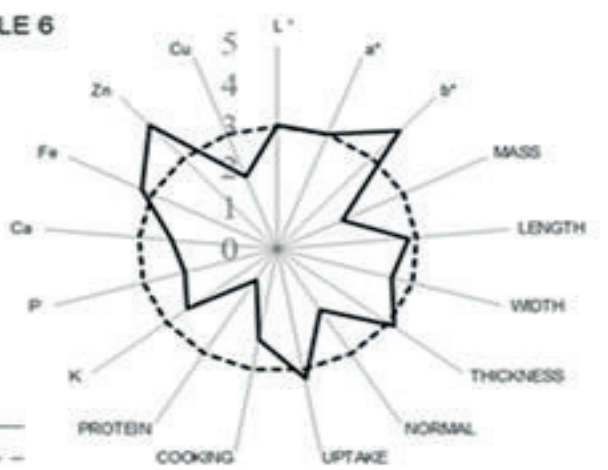

In the present study, the use of the $\bar{Z}$ index enabled the determination that sample 4 had the best visual, technological, cooking and nutritional quality among the commercial brands of carioca beans evaluated. In this case, when the consumers of carioca beans selected sample 4 based on visual

quality traits (colour and grain size), they bought a food with higher technological quality, fast cooking time and high nutritional value. This allows us to infer that the results obtained by the carioca bean breeding programmes in this research line are already available in the supermarkets and meet consumer preference. 


\section{Conclusions}

The visual quality traits, colour and grain size, define consumer choice of carioca beans. Commercial brands of carioca beans present differences in their technological, cooking and nutritional quality traits. Carioca beans from brand 4 were the preference of $51.92 \%$ of the survey participants, and it is the best commercial brand of carioca beans marketed in southern Brazil for its technological, cooking and nutritional quality traits.

\section{Acknowledgements}

To the Conselho Nacional de Desenvolvimento Científico e Tecnológico (CNPq) for financial support and scholarships. To the Coordenação de Aperfeiçoamento de Pessoal de Nível Superior (CAPES) for the grants awarded.

\section{References}

ARAÚJO, L. C. A. de.; RAMALHO, M. A. P.; ABREU, A. de F. B. Estimates of genetic parameters of late seedcoat darkening of carioca type dry beans. Ciência $e$ Agrotecnologia, Lavras, v. 36, n. 2, p. 156-162, 2012.

ARNS, F. D.; RIBEIRO, N. D.; MEZZOMO, H. C.; STECKLING, S. de M.; KLÄSENER, G. R.; CASAGRANDE, C. R. Combined selection in carioca beans for grain size, slow darkening and fast-cooking after storage times. Euphytica, Wageningen, v. 214, n. 4, p. 1-12, 2018.

ASSOCIATION OF OFFICIAL ANALYTICAL CHEMISTS - AOAC. AOAC International. Official methods of analysis of AOAC. $16^{\text {th }}$ ed. Gaithersburg: Association of Analytical Communities, 1995. 2000 p.

BARROS, M. de; PRUDENCIO, S. H. Physical and chemical characteristics of common bean varieties. Semina: Ciências Agrárias, Londrina, v. 37, n. 2, p. 751762, 2016.

BERNARDO, L. M. Histórias da luz e das cores. Porto: Universidade do Porto, 2010. 510 p.

CÂMARA, C. R. S.; URREA, C. A.; SCHLEGEL, V. Pinto beans (Phaseolus vulgaris L.) as a functional food: implications on human health. Agriculture, Basel, v. 3, n. 1, p. 90-111, 2013.
CARBONELL, S. A. M.; CHIORATO, A. F.; GONÇALVES, J. G. R.; PERINA, E. F.; CARVALHO, C. R. L. Tamanho de grão comercial em cultivares de feijoeiro. Ciência Rural, Santa Maria, v. 40, n. 10, p. 2067-2073, 2010.

CARNEIRO, J. E. S.; ABREU, A. F. B.; RAMALHO, M. A. P.; PAULA JÚNIOR, T. J.; DEL PELOSO, M. J.; MELO, L. C.; PEREIRA, H. S.; PEREIRA FILHO, I. A.; MARTINS, M.; VIERA, R. F.; MARTINS, F. A. D.; COELHO, M. A. de O.; CARNEIRO, P. C. de S.; MOREIRA, J. A. A.; SANTOS, J. B. dos; FARIA, L. C. de; COSTA, J. G. C. da; TEIXEIRA, H. Cultivar realease - BRSMG Madrepérola: common bean cultivar with latedarkening Carioca grain. Crop Breeding and Applied Biotechnology, Viçosa, MG, v. 12, n. 4, p. 281-284, 2012.

CRUZ, C. D. Genes software - extended and integrated with the R, Matlab and Selegen. Acta Scientiarum Agronomy, Maringá, v. 38, n. 4, p. 547-552, 2016.

CZAJKA-NARINS, D. M. Minerais. In: KATHLEEN, M. L. Krause: alimentos, nutrição e dietoterapia. São Paulo: Roca, 1998. p. 123-166.

DI BELLA, G.; NACCARI, C.; BUA, G. D.; RASTRELLI, L.; LO TURCO, V.; POTORTI, A. G.; DUGO, G. Mineral composition of some varieties of beans from Mediterranean and Tropical areas. International Journal of Food Sciences and Nutrition, Parma, v. 67, n. 3, p. 239-248, 2016.

FRANCO, G. Tabela de composição química dos alimentos. $9^{\text {th }}$ ed. Rio de Janeiro: Atheneu, 2005. 324 p.

GATHU, W. E.; KARURI, E. G.; NJAGE, P. M. K. Physical characterization of new advanced drought tolerant common bean (Phaseolus vulgaris) lines for canning quality. American Journal of Food Technology, Dubai, v. 7, n. 1, p. 22-28, 2012.

GIBSON, R. Zinc deficiency and human health: etiology, health consequences, and future solutions. Plant and Soil, Crawley, v. 361, n. 1, p. 291-299, 2012.

HE, F. J.; MACGREGOR, G. A. Beneficial effects of potassium on human health. Physiologia Plantarum, Copenhagem, v. 133, n. 4, p. 725-735, 2008.

JOST, E.; RIBEIRO, N. D.; MAZIERO, S. M.; POSSOBOM, M. T. D. F.; ROSA, D. P.; DOMINGUES, L. da S. Comparison among direct, indirect and index selections on agronomic traits and nutritional quality traits in common bean. Journal of the Science of Food and Agriculture, London, v. 93, n. 5, p. 1097-1104, 2013.

MARTÍNEZ-BALLESTA, M. C.; DOMINGUEZPERLES, P.; MORENO, D. A.; MURIES, B.; ALCALAZ-LÓPEZ, C.; BASTÍAS, E.; GARCÍA- 
VIGUERA, C.; CARVAJAL, M. Minerals in plant food: effect of agricultural practices and role in human health. A review. Agronomy for Sustainable Development, Paris, v. 30, n. 2, p. 295-309, 2010.

MAZIERO, S. M.; RIBEIRO, N. D.; STORCK, L. Simultaneous selection in beans for architecture, grain yield and minerals concentration. Euphytica, Wageningen, v. 205, n. 2, p. 369-380, 2015.

MENDES, F. F.; RAMALHO, M. A. P.; ABREU, A. de F. B. Índice de seleção para escolha de populações segregantes de feijoeiro comum. Pesquisa Agropecuária Brasileira, Brasília, v. 44, n. 10, p. 1312-1318, 2009.

MESSINA, V. Nutritional and health benefits of dried beans. The American Journal of Clinical Nutrition, Oxford, v. 100, p. 437S- 442S, 2014. Supplement.

MINGOTTE, F. L. C.; GUARNIERI, C. C. de O.; FARINELLI, R.; LEMOS, L. B. Desempenho produtivo e qualidade pós-colheita de genótipos de feijão do grupo comercial carioca cultivados na época de invernoprimavera. Bioscience Journal, Uberlândia, v. 29, n. 5, p. 1101-1110, 2013.

OLIVEIRA, V. R. de; RIBEIRO, N. D.; MAZIERO, S. M.; CARGNELUTTI FILHO, A.; JOST, E. Qualidade para o cozimento e composição nutricional de genótipos de feijão com e sem armazenamento sob refrigeração. Ciência Rural, Santa Maria, v. 41, n. 5, p. 746-752, 2011.

PEREIRA, H. S.; ALVARES, R. C.; MELO, L. C.; COSTA, A. F. da C.; CARVALHO, H. W. L. de. Culinary and nutritional quality of common bean lines with Carioca grain type and interaction with environments. Revista Ceres, Viçosa, MG, v. 64, n. 2, p. 159-166, 2017.

PINHEIRO, C.; BAETA, J. P.; PEREIRA, A. M.; DOMINGUES, H.; RICARDO, C. P. Diversity of seed mineral composition of Phaseolus vulgaris L. germplasm. Journal of Food Composition and Analysis, Amsterdam, v. 23, n. 4, p. 319-325, 2010.

PUERTA ROMERO, J. Variedades de judias cultivadas en España. Madrid: Ministério da Agricultura, 1961. 198 p.

RANI, P. R.; CHELLADURAI, V.; JAYAS, D. S.; WHITE, N. D. G.; KAVITHA-ABIRAMI, C. V. Storage studies on pinto beans under different moisture contents and temperature regimes. Journal of Stored Products Research, Amsterdam, v. 52, n. 1, p. 78-85, 2013.

RESENDE, M. D. V. de; DUARTE, J. B. Precisão e controle de qualidade em experimentos de avaliação de cultivares. Pesquisa Agropecuária Tropical, Goiânia, v. 37, n. 3, p. 182-194, 2007.
RIBEIRO, N. D.; DOMINGUES, L. da S.; GRUHN, E. M.; ZEMOLIN, A. E. M.; RODRIGUES, J. de A. Desempenho agronômico e qualidade de cozimento de linhagens de feijão de grãos especiais. Revista Ciência Agronômica, Fortaleza, v. 45, n. 1, p. 92-100, 2014.

RIBEIRO, N. D.; DOMINGUES, L. da S.; ZEMOLIN, A. E. M.; POSSOBOM, M. T. D. F. Selection of common bean lines with high agronomic performance and high calcium and iron concentrations. Pesquisa Agropecuária Brasileira, Brasília, v. 48, n. 10, p. 1368-1375, 2013 b.

RIBEIRO, N. D.; LONDERO, P. M. G.; CARGNELUTTI FILHO, A.; JOST, E.; POERSCH, N. L.; MALLMANN, C. A. Composição de aminoácidos de cultivares de feijão e aplicações para o melhoramento genético. Pesquisa Agropecuária Brasileira, Brasília, v. 42, n. 10, p. 13931399, 2007.

RIBEIRO, N. D.; MAMBRIN, R. B.; STORCK, L.; PRIGOL, M.; NOGUEIRA, C. W. Combined selection for grain yield, cooking quality and minerals in the common bean. Revista Ciência Agronômica, Fortaleza, v. 44, n. 4, p. 869-877, 2013a.

RIBEIRO, N. D.; STORCK, L.; POERSCH, N. L. Classificação de lotes comerciais de feijão por meio da claridade do tegumento dos grãos. Ciência Rural, Santa Maria, v. 38, n. 7, p. 2042-2045, 2008.

SANTOS, G. G. dos; RIBEIRO, N. D.; MAZIERO, S. M. Evaluation of common bean morphological traits identifies grain thickness directly correlated with cooking time. Pesquisa Agropecuária Tropical, Goiânia, v. 46, n. 1, p. 35-42, 2016.

SILVA, C. A.; ABREU, A. F. B.; RAMALHO, M. A. P.; MAIA, L. G. S. Chemical composition as related to seed color of common bean. Crop Breeding and Applied Biotechnology, Viçosa, MG, v. 12, n. 2, p. 132-137, 2012.

SILVA, M. B. de O.; CARVALHO, A. J.; CARNEIRO, J. E. de S.; ASPIAZÚ, I.; ALVES, É. A.; DAVID, A. M. S. de S.; BRITO, O. G.; ALVES, P. F. S. Technological quality of grains of common beans selected genotypes from the carioca group. Semina: Ciências Agrárias, Londrina, v. 37, n. 4, p. 721-732, 2016.

SIQUEIRA, B. S.; BASSINELLO, P. Z.; MALGARESI, G.; PEREIRA, W. J.; FERNANDES, K. F. Analyses of technological and biochemical parameters related to the HTC phenomenon in carioca bean genotypes by the use of PCA. LWT - Food Science and Technology, Berlim, v. 65, n. 1, p. 939-945, 2016 b.

SIQUEIRA, B. S.; BASSINELLO, P. Z.; SANTOS, S. C.; MALGARESI, G.; FERRI, P. H.; RODRIGUES, G. A.; FERNANDES, K. F. Do enzymatic or non-enzimatic 
pathways drive the postharvest darkening phenomenon in carioca bean tegument? LWT - Food Science and Technology, Berlim, v. 69, n. 6, p. 593-600, 2016 a.

SIQUEIRA, B. S.; PEREIRA, W. J.; BATISTA, K. A.; OOMAH, B. D.; FERNANDES, K. F.; BASSINELLO, P. Z. Influence of storage on darkening and hardening of slow- and regular-darkening carioca bean (Phaseolus vulgaris L.) genotypes. Journal Agricultural Studies, Las Vegas, v. 2, n. 1, p. 87-104, 2014.

STECKLING, S. de M.; RIBEIRO, N. D.; ARNS, F. D.; MEZZOMO, H. C. Genetic diversity and selection of common bean lines based on technological quality and biofortification. Genetics and Molecular Research, Ribeirão Preto, v. 16, n. 1, p. 1-13, 2017.
TRYPHONE, G. M.; NCHIMBI-MSOLLA, S. Diversity of common bean (Phaseolus vulgaris L.) genotypes in iron and zinc contents under screenhouse conditions. Journal of Agricultural Research, Lahore, v. 5, n. 8, p. 738-747, 2010.

ZIMMERMANN, L. de. O. G.; COELHO, S. R. M.; CHRIST, D.; NÓBREGA, L. H. P. Alterações da qualidade tecnológica de marcas comerciais de feijão dos grupos cores e preto. Semina: Ciências Agrárias, Londrina, v. 30, n. 3, p. 619-628, 2009. 